\title{
The Phenomenon of Chinese Female Print Artists' Creative Activities in the 13th National Exhibition of Fine Arts
}

\author{
Jingkun $\mathrm{Qi}^{1{ }^{1, *}}$
}

\author{
${ }^{1}$ Shanxi University, Taiyuan, Shanxi, China \\ *Corresponding author.Email:403395103@qq.com
}

\begin{abstract}
The research object in this paper is the selected female print artists of the 13th National Exhibition of Fine Arts. This paper analyzes the rules of their participation activities on the basis of data. The study found many characteristics, such as: there is a significant difference in the gender ratio of the selected artists; there are gender differences in creative activity cycle; social gender influences women's creative activities; the selection system of art exhibition has some restrictions on the participation of female artists. At the last, the article discusses the female print artists' creation activities through the description of selected female in the 13th National Exhibition of Fine Arts.
\end{abstract}

\section{Keywords: print, female artists, creation, National Exhibition of Fine Arts}

\section{INTRODUCTION}

The Chinese female artist's creation activities have been drawing public's attention since social status and educational level of women risen. In fact, in this paper we found out there is still a long distance for female artists to conquer due to the phenomenon of Chinese female print artist's creative activities in the 13th National Exhibition of Fine Arts.

\section{THE APPEARANCE OF FEMALE ARTISTS IN THE 13TH NATIONAL ART EXHIBITION}

Firstly, the proportion of female selected artists in the 13th national art exhibition is low, but the trend of the proportion is on the rise as a whole. Statistically speaking, the proportion of female applicants is lower than that of male applicants; But the percentage of women who are selected is increasing. Statistics show that among the selected artists in the 13th exhibition, the gender imbalance is significant. The gender of 308 artists was known in the sample[1], of which 227 were male artists, accounting for $73.70 \%$. Female artists accounted for 81 of 26.30 percent. (data uses the trend analysis method and comparative analysis method, the selected artists and judges data classification, respectively according to: selected artists gender, average age, the age distribution (strong, weaken). From the classified statistics and comparison, the male and female data comparison, the men and women, respectively, compared with general again. Engraving area selected artists 379 (340 selected works, the author) total of 379 people, of whom 71 failed to determine gender, 81 women, 227 men and women selected artists $26.30 \%$. Compared with the previous data, the gender imbalance of some artists in the national art exhibition prints has always existed. In the 13th national art exhibition, the proportion of female candidates was the highest. Although the number of female artists in the national art exhibition is still in a lower position than before, the proportion is gradually increasing. Since the 6th national art exhibition in 1984 , the number of female artists has changed significantly.

Moreover, there is a cycle difference with gender characteristics in female participation in artistic creation activities, which is described in this paper as "cycle difference in artistic creation activities". When it comes to artistic creation, men are generally better than women. According to the age of the selected persons in the 13th national art exhibition, the average age of the 236 age samples collected is 43.12 years old (mean $r$ =43.12334). Among the 178 men, the age range was from 23 to 70, with an average age of 58.00.The sample of 58 women ranged from 22 years old to 58 years old. The average age of female artists is 35.36. Men are above average and women below average. Female creative activity is relatively stable at 29-49 years old, while male creative activity is relatively stable at 39-69 years old. In contrast, men's creative activity was more stable than women's for about 10 years.(female cycle occurs at different stages of 29-39 years old, 45-49 years old and 50-54 years old, and the number of female cycle remains at about 7 , with the difference between $\leq 2$ and $\geq 1$ ). Before the age of 29 , there was no significant difference in the cycle of creative activity, and there was a small difference in the level of creative 
activity between men and women between the ages of 20 and 29. Differentiation began at age 29 (the number of males continued to rise after age 29, while the number of females began to decline), and the active degree of creative activities from age 29 to 39 showed obvious differentiation. From 25 to 29 years old, female creative activities are most vigorous. At the age of 45, there was an overall decreasing trend in female creative activities. At the age of 69 , there was an overall decline in male creative activities. Different from women, the age of male artists varies from one session to another. According to statistics, the age of creation continues to be after 70 years old, while women are not selected after 59 years old.

\section{THE PHENOMENON ANALYSIS SHOWS THAT THE FEMALE CANDIDATES OCCUPY A LOWER PROPORTION THAN THE MALE ONES}

There is a correlation between economic development and women's participation. Except for traditional areas such as Heilongjiang and Yunnan, as well as Sichuan, where some prints of this exhibition were held, the level of economic development is positively correlated with those selected. However, the correlation between the proportion of female candidates and the regional economic development level is not strong, while the increase of the number of female candidates is related to the overall economic development level. We make the following analysis: from the rising trend of women's economic independence level[2], related papers have discussed the relationship between women's economic independence level and the age of marriage and childbearing, which usually leads to the conclusion that economic independence will delay the age of marriage and childbearing for women. In this sense, the flourishing period of women's creative activities will be extended accordingly. From the perspective of research, we make a hypothesis: compared with the previous female creative activities in several national art exhibitions, we observe whether this age tends to increase gradually.

Secondly, the proportion of female judges is low. There were 17 judges in the woodcut section of the 13th national art exhibition, including 2 women and 15 men. The proportion of female judges was $11.76 \%$; among the selected artists, female accounted for $26.30 \%$, and the selection of female artists was similar to that of female judges. However, in the judging process, we cannot judge whether the selection of female artists' works will affect the selection factors, nor can we judge whether female judges can have a corresponding selection tendency under the circumstance of blind review in the selection process. But we can see a phenomenon, the female judges in the overall composition of the judges is really low.
Moreover, as far as the judging criteria are concerned, the judging criteria for the national art exhibition are not required by the size of ruler, but for the selected works, the size of the selected works is at least $30 \times 60 \mathrm{~cm}$, and more than $85 \%$ of the selected works exceed $100 \times 100 \mathrm{~cm}^{2}$. Engraving creation emphasizes the property and production of tools, and the work with a large ruler will be difficult in the process of completion. In general, due to the physical conditions in the creation activities, women have some disadvantages compared with men in making large scale works. Comparing the International Exlibris and Mini-prints Biennial and illustration exhibition, it can be seen that the proportion of male and female in this type of exhibition is basically equal. Compared with the $26.30 \%$ proportion of female entrants in the national art exhibition, the phenomenon of seeking a larger scale of works seems to be a barrier to women's participation. Women show a better participation in the same type of art exhibition with a smaller scale. According to the 17th international Exlibris and Mini-prints in 2018 calling requirements, the works size requirements in the "images maximum size shall not exceed $15 \mathrm{~cm}$ length, small pieces of" frame length must be between 15 to 30 $\mathrm{cm}$, images should be white space around the edge of 3 $5 \mathrm{~cm} "$, in the these selection case, men and women entrants proportion were mainly equals. Therefore, the pursuit of the creation of a large ruler has an impact on the participation of women in national art exhibitions, or the selection of women's works in national art exhibitions. There is a similar phenomenon in the selection of the second illustrated art exhibition in China in 2019, and the selection of men and women is relatively balanced: $51.00 \%$ of men and $49.00 \%$ of women participate in the exhibition.

\section{THE CHANGE OF EDUCATIONAL CONDITIONS AND THE INCREASING PROPORTION OF FEMALE CANDIDATES HAVE A POSITIVE IMPACT}

According to the statistical results of the sixth session in 1984[3], the ninth session in 1999, the eleventh session in 2009, the twelfth session in 2014 and the thirteenth session in 2019, female artists began to participate in the exhibition in the printmaking area of the national art exhibition from the third session in 1960 , and the number began to increase significantly in 1984.

The change of women's educational conditions: the proportion of women in higher education is increasing [4]. Since the founding of the People's Republic of China, with the rapid economic development, especially after the reform and opening up, women's educational level has been continuously improved, and their participation in printmaking has been correspondingly increased. From a macro point of view, since the 
founding of the People's Republic of China, the proportion of female students in higher education has increased year by year. Taking the academy of fine arts as an example, women are more inclined to choose this major and the number is on the rise. "According to incomplete statistics, women accounted for 63 percent of the undergraduate and graduate enrollment in Chinese art universities in 2018, with the eight major art schools as the main body. Female students account for nearly $80 \%$ of the 2018 and 2019 undergraduate students of the China academy of fine arts. Female students account for $72 \%$ of the 2018 freshmen of Nanjing university of the arts. Female undergraduates of the 2017 central academy of fine arts accounted for 71 percent. Among the art majors in normal universities, taking Changsha normal university in Hunan province as an example, female students account for $80 \%$ of the total number of students. Among the selected female artists, $63.79 \%$ have a master's degree, and $48.65 \%$ of the artists with a master's degree graduated from professional art schools. Among them, $46.55 \%$ are currently studying or have just graduated (the selected works include works from the university), 27 female artists from 20 to 29 years old are currently studying or have just graduated with a master's degree, and $36.21 \%$ are engaged in teaching, most of whom are university teachers. There are 21 selected university teachers, and the students and teachers form the main part of the selected teachers. The prolonged teaching time every year means that women have more time and conditions for creation than in the past, so as to promote the sustainable development of their own print creation. The increasing number of women receiving higher art education can reflect the increasing number of people selected in the 13th national art exhibition from one side. We see a phenomenon in the statistics, 29, is usually a time of receiving higher education before, that is, before the age of 29, men and women can be a good economic environment support, completed the undergraduate or graduate studies, this one phase of the learning outcomes constitute the list also more concentrated in the age of reason, can see, there is considerable part of the selected works from during the period of school work, or graduation creation.

\section{THE CHARACTERISTICS OF GENDER DIFFERENCE REFLECTED IN "DIFFERENCE OF CREATIVE ACTIVITY CYCLE"}

There was no significant gender difference before age 29. From the perspective of gender sociology, there is no significant difference between women and men in artistic creation at this stage. As mentioned above, women are usually in undergraduate and graduate education before the age of 29 , and before marriage and childbirth. In this stage, no matter women are not yet financially independent, they mainly depend on their parents or have a certain independent economic basis.
Therefore, the relatively undetermined financial resources can guarantee their study and artistic creation activities. After the age of 29 , women gradually enter the society, although social work has diverted a part of female artists engaged in print creation; In addition, marriage, childbirth and child rearing are important factors that influence women to continue to engage in artistic creation. Interviews with individual female artists show that taking care of their families is the most common reason for them to put down their creation.

Women enter the prime marriage and child-bearing age after age 29 . Under the influence of fertility, the differentiation of creative activity degree caused by gender difference ("difference in creative activity cycle") appeared after the age of 29 , and the female activity degree showed a declining trend, while the female creative activity degree between the age of 25 and 30 experienced a great transition. The average marriage age for women in all provinces was between 26 and 35 in 2018. The role of women in society and families affected by society and traditional culture, make the most of the women in the face of marriage and family sacrifice part of or even give up in the family moved to career, when women enter the examination after 29 years old from a drop in the number for alternative at the age of 20 to 29 the rise trend, visible examination affect the female artists creation activity. In 1979, reform and opening up accelerated the economic growth, women became increasingly independent, and the age of marriage and childbearing was constantly postponed. At the same time, they have more employment options and the ability and conditions for further study. In the past, women's marriage and childbearing and the role of family after marriage were the main reasons for female artists to give up their creative activities in this age group. A good economic environment is a prerequisite for female artists to engage in printmaking. In a time of good economic and social development, the relevant culture, life and ethical concepts will have an impact on this. Generally speaking, with the gradual improvement of the economic level, women's pursuit of individual career will also be improved, and the time and energy invested in artistic creation will also be increased accordingly.

After 45 years of age is a turning point, when most of the physical is experiencing menopausal women artists, accompanied by the phenomenon of most appear menopause symptoms, falling body system function and hormone disorder may affect women's normal work and life, at this time the creation of the active level also showed a drop. According to "investigation on the influencing factors of the age of menopause in Chinese urban women" - menopausal women accounted for $82.45 \%$ of the $45-54$ - year - olds. 


\section{CONCLUSION}

In terms of universality, the national art exhibition is an important bridge between the Chinese art creation group and the people's aesthetic needs. The presentation of works should be able to reflect the general spiritual outlook and spiritual appeal of the people under the historical circumstances. Therefore, the difference in the gender of creators in the balanced degree of participation in the creation activities of national art exhibitions cannot well reflect this significance. Taking women's print creation activities as an example, through sorting out statistics, it is found that female artists show a weak participation in the edition exhibition areas of national art exhibitions. Further analysis reveals that women have many restrictions on the external conditions and influencing factors of their creative activities. However, in terms of its artistic noumenon, there is no gender difference in artistic creation activities. In other words, although women show different characteristics and characteristics from men in artistic creation, there should be no difference caused by gender constraints in the process of enjoying artistic creation and exploring aesthetic essence.

Furthermore, through the analysis, we try to find the reasons behind the differences and find that there are some hidden correlations between the economic, social and institutional factors related to the background of national art exhibitions and the "participation" of female artists. To be specific: firstly, economic development factors have an indirect impact on women's engagement in artistic creation. Simply put, the improvement of women's independent ability as a result of economic development is conducive to women's engagement in artistic creation, including the relevant education level; secondly, in the family relationship under the current social background in China, women's attitudes towards marriage and childbirth constitute an important factor for their participation in artistic creation activities, and the factors that influence their participation in artistic creation activities in national art exhibitions; thirdly, in the context of the evaluation system of the exhibition, although there is no clear in eligibility $\mathrm{CheFu}$ technique, and works in the limit, but see from selected works analysis, BanZhong trade-off is no significant gender differences, but BanZhong choose pluralism participation of women have a certain influence, such as: digital version may be used against female artists of physical constraints, but did not see a digital version of work in this exhibition was selected.(the controversy of the digital version itself is not the content of this article, but from my personal point of view, the level of art in the work is not only restricted by the means of creation, but the embodiment of the content of the work). In addition, the overall creation trend and review preference of works with a larger overall scale indirectly affect the participation of female engraving artists. (as is the case with printmaking, due to the technical problems of this kind of painting, ruler usually restricts artists' creative activities, which is obvious among female artists.) We compared the exhibitions of book tickets, small prints and illustrations, and found that in these two categories which are easy to master, female participation has a significantly high proportion.

As for the research work of national art exhibition, I also suggest that the phenomenon of artistic creation should be studied, and the perspective of art research and art criticism should be introduced into a comprehensive analysis in the context of sociology, education, economics and other comprehensive disciplines rather than a single description. For example, when sorting out the data of this paper, the difficulties we encountered were reflected in the process of obtaining information about the participation in national art exhibitions, selected artists and judges, which was objectively not effective enough. I think, if the literature materials behind each national beauty exhibition can be sorted out in a better and more standardized way, it will be convenient for the majority of researchers to study this, which is also conducive to the development of domestic art creation.

\section{References}

[1] Information on http://www.caanet.org.cn/

[2] Information on http://data.stats.gov.cn.

[3] Chinese Artists Association. The 6TH national art exhibition., Popular fine arts publishing house, 1984.

[4] Information on http://www.moe.gov.cn/.

[5] Huang Junxian. "How to develop female art education in accounting for nearly $70 \%$ of art students in colleges?" $[\mathrm{N}]$ Art Paper, 2019(12-12).

[6] Xiangyang. Fertility and Age. Encyclopedia of Knowledge [J]. 2005(11) 37-38 